\title{
8
}
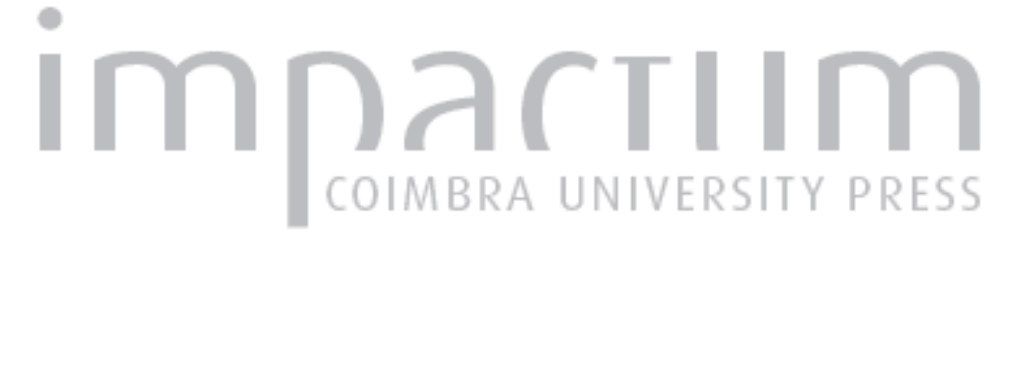

\section{A Carta Educativa Municipal como instrumento estratégico de reorganização da rede educativa: tendências de mudança}

Autor(es): $\quad$ Cordeiro, A. M. Rochette; Martins, Helena Arcanjo

Publicado por: $\begin{aligned} & \text { Faculdade de Letras da Universidade de Coimbra, Departamento de } \\ & \text { Geografia }\end{aligned}$

URL

persistente:

URI:http://hdl.handle.net/10316.2/30267

DOI:

DOI:http://dx.doi.org/10.14195/0871-1623_32_28

Accessed : $\quad$ 26-Apr-2023 11:40:35

A navegação consulta e descarregamento dos títulos inseridos nas Bibliotecas Digitais UC Digitalis, UC Pombalina e UC Impactum, pressupõem a aceitação plena e sem reservas dos Termos e Condições de Uso destas Bibliotecas Digitais, disponíveis em https://digitalis.uc.pt/pt-pt/termos.

Conforme exposto nos referidos Termos e Condições de Uso, o descarregamento de títulos de acesso restrito requer uma licença válida de autorização devendo o utilizador aceder ao(s) documento(s) a partir de um endereço de IP da instituição detentora da supramencionada licença.

Ao utilizador é apenas permitido o descarregamento para uso pessoal, pelo que o emprego do(s) título(s) descarregado(s) para outro fim, designadamente comercial, carece de autorização do respetivo autor ou editor da obra.

Na medida em que todas as obras da UC Digitalis se encontram protegidas pelo Código do Direito de Autor e Direitos Conexos e demais legislação aplicável, toda a cópia, parcial ou total, deste documento, nos casos em que é legalmente admitida, deverá conter ou fazer-se acompanhar por este aviso.

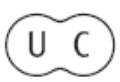




\title{
A Carta Educativa Municipal como instrumento estratégico de reorganização da rede educativa: tendências de mudança
}

\author{
A. M. Rochette Cordeiro \\ Departamento de Geografia e Centro de Estudos de Geografia e Ordenamento do Território (CEGOT). Faculdade de Letras da Universidade de Coimbra. \\ rochettecordeiro@fl.uc.pt
}

\section{Helena Arcanjo Martins}

Doutoranda em Ciências da Educação na Universidade de Aveiro.

helenaarcanjo@gmail.com

\section{Resumo:}

Em Portugal, desde 2005 que se tem vindo a assistir, de forma intensiva, e por vezes de forma algo abusiva, à assunção da Carta Educativa enquanto instrumento legitimador do planeamento estratégico e do reordenamento prospetivo das redes educativas municipais. Os efeitos mais visíveis do seu uso, no caso do $1^{\circ} \mathrm{Ciclo}$ do Ensino Básico, traduzem-se na requalificação e aumento de escala dos estabelecimentos de ensino, na retração quantitativa e na distribuição pelo território. Na sua origem estão o encerramento de milhares de escolas e a construção de centenas de Centros Escolares.

Sustentada numa investigação desenvolvida junto de 14 municípios da região centro, apresenta-se, ainda que de forma breve e não definitiva, a análise das tendências de reordenamento da rede preconizadas nas respetivas Cartas Educativas: (i) reorganização do "tipo decretado"; (ii) reordenamento do "tipo conciliação"; (iii) reordenamento do "tipo comunitário". Observa-se ainda a "visão municipal" e a "visão das equipas técnicas" sobre o processo da elaboração da Carta Educativa, sendo possível concluir, entre outras, a importância da sustentação técnica como apoio à mediação e decisão política, no âmbito municipal.

Palavras-chave: Cartas educativas. Municípios. Reorganização da rede educativa. Documento estratégico.

\section{Resumé:}

La Charte Éducative Municipale comme instrument stratégique de réorganisation du réseau éducatif: changement de tendances

Depuis 2005, au Portugal on assiste de forme intensive et quelquefois de façon abusive à l'assomption de la Charte Éducative en tant qu'instrument légitimateur de la planification stratégique et du réordonnement prospectif des réseaux éducatifs municipaux. Les effets les plus visibles de son utilisation, en ce qui concerne le cas de l'école primaire, se traduisent par la requalification et l'augmentation d'échelle des établissements scolaires, au niveau de la rétraction quantitative et de la distribution sur le territoire. La fermeture de milliers d'écoles et la construction de Centres Scolaires sont à l'origine de tout cela. Une recherche basé sur 14 municipalités de la région centre, présente, d'une forme encore brève et non définitive, l'analyse des tendances de réordonnement du réseau préconisé sur les perspectives Chartes Educatives: (i) réorganisation du "type décrété"; (ii) réordonnement du "type conciliation"; (iii) réorganisation du "type communautaire". On observe aussi, la "vision municipale" et la "vision des équipes téchniques" sur le processus d'élaboration de la Charte Educative, étant possible conclure, entre autre, l'importance de la défense téchnique comme support à la médiation et à la décision politique, au niveau municipal.

Mots-clés: Charte Educative. Municipalités. Réordonnement du réseau educative. Document stratégique. 


\section{Abstract:} The municipal educative charter as a strategic instrument for the reorganization of the educative network: changing
tendencies

Since 2005, in Portugal, people have been looking at the Educative Letter, sometimes in an abusive way, as legitimate instrument for the strategic planning and the reordering of the municipal educational nets. In the case of the basic Schooling, the most visible effects are the requalification and the increase of the number of Institutions and in the quantitative retraction and distribution in the territory. These situations are a result from the closing of thousands of schools and the construction of hundreds of School Centres.

This analysis is based on the investigation on 14 municipals of the Centre of Portugal, and is presented as a brief but not definitive analysis of the land reorder tendencies of the Educative Letters: (i) "decree type" reorder; (ii) "conciliation type" reorder; (iii) "community type" reorder". There is also the "municipal view" and the "technical teams view" on the whole process of the Educative Letter elaboration, and it is possible to define the importance of the technical support on the political mediation and decision.

Keywords: Educative Letters. Municipals. Educative net reorder and Strategic Document.

\section{Introdução}

As características do modelo de rede escolar pública ${ }^{1}$ edificado em Portugal, ao longo do século XX, alteraram-se, significativamente, durante a última década. Orientada por padrões de qualidade, modernização, eficácia e equidade, assente em modelos de planeamento prospetivo e de gestão local, a rede escolar (especialmente a do $1^{\circ}$ ciclo e da educação pré-escolar) apresenta consideráveis alterações morfológicas: está menos dispersa, mais requalificada e modernizada, composta por novas escolas e tipologias, organizada em agrupamentos de escolas e mais ajustada aos padrões que caracterizam a sociedade portuguesa atual (Matthews et al., 2009; Rodrigues, 2010; Cordeiro, 2011). Indicadores que a distanciam dos resultados produzidos durante o período de expansão onde imperou um modelo centralizado de planificação e definição da rede escolar, distante da realidade local e orientado por uma "visão quantitativa" centrada no aumento de estabelecimentos e de vagas. Ou seja, um modelo governado pelo Estado central e regulado pela oferta (MACEDo e Afonso, 2002; Barroso e Viseu, 2003).

Parece ser inquestionável que a Carta Educativa (Decreto-lei n. 7/2003, de 15 de Janeiro), desempenhou um papel relevante na transformação e modernização da rede escolar pública portuguesa, em especial, no $1^{\circ}$ Ciclo do Ensino Básico que exigia uma intervenção sisté-

${ }^{1}$ A rede escolar do ensino não superior, em Portugal, é constituída por estabelecimentos de natureza pública e privada. Ao contrário de outros países (Brasil, Espanha) a rede escolar é maioritariamente, pública. Os dados oficiais mais recentes (ME, 2011b) indicam que, no ano letivo 2009/2010, a rede escolar era constituída por um total de 17141 estabelecimentos de ensino, dos quais 84,8 \% são públicos (14 533 estabelecimentos de ensino). mica $^{2}$ (Rodrigues, 2010; MAtThews et al., 2009). As Cartas Educativas são documentos oficiais da iniciativa do poder central e de âmbito do ordenamento do território, a serem equacionados pelos poderes locais, embora de acordo com critérios e limites definidos centralmente. Têm como meta, no plano teórico-normativo, "melhorar o ensino, através de uma utilização eficaz dos edifícios escolares e dos equipamentos de um determinado território" (ME, 2011c, p. 4).

Enquanto instrumento legitimador do reordenamento e requalificação da rede educativa municipal, a Carta Educativa ocupa-se do planeamento prospetivo das necessidades de equipamentos e recursos para as modalidades de ensino e educação não superior: o ensino regular, a educação especial, o ensino profissional, o ensino recorrente e a educação extra-escolar, (modalidades de educação definidas pela Lei de Bases do Sistema Educativo), tendo em vista a melhor utilização dos recursos educativos. A sua elaboração e concretização são realizadas tendo em conta o quadro do desenvolvimento demográfico e socioeconómico de cada município e de acordo com as ofertas de educação e formação que seja necessário satisfazer. Nessa medida, deve ter em conta não só "a realidade atual mas, fundamentalmente, uma perspetiva do que deverá ser a oferta e a procura nas próximas décadas" (CORDEIRO, 2011).

2 Para ultrapassar a condição de "parente pobre do sistema", o XVII Governo, em 2005, elegeu o $1^{\circ}$ Ciclo como prioridade. Entre as várias medidas encetadas para este sector, encontrava-se a elaboraça das cartas educativas e a reorganização da rede escolar: "a intenção é encontrar soluções para o encerramento de escolas com menos de 20 alunos e taxas de aproveitamento inferiores à média nacional, assegurando condições para o fecho das mesmas (...) é de salientar que esta medida vai exigir um esforço de investimento em escolas ou centros escolares onde as crianças passam a beneficiar de condições de aprendizagem mais moderna e consentâneas com a integração do país no espaço europeu" (ME, 2005, p.14) 
A fim de evitar ruturas e desadequações da rede educativa em função do desenvolvimento económico, sociocultural e urbanístico do território de pertença, a Carta Educativa leva à tomada de decisões relativamente à construção de novos estabelecimentos de ensino, ao encerramento de escolas e à reconversão e adaptação de estabelecimentos de ensino. Pretende-se assim assegurar a adequação atual e futuro do ordenamento da rede de estabelecimentos de ensino não superior, para que as ofertas educativas disponíveis a nível municipal possam responder à procura efetiva, o mesmo se passando com o refletir, a nível municipal, do processo de ordenamento a nível nacional da rede de ofertas de educação e formação, com vista a assegurar a racionalização e complementaridade dessas ofertas e o desenvolvimento qualitativo das mesmas. De igual modo, deve promover o desenvolvimento do processo de agrupamento de escolas, com vista à criação nestas das condições mais favoráveis ao desenvolvimento de centros de excelência e de competências educativas, bem como garantir a coerência da rede educativa com a política urbana do município (artigo $11^{\circ}$ do Decreto-lei n. $\left.{ }^{\circ} 7 / 2003\right)$.

Neste contexto, a Carta Educativa é assumida desde a sua génese como um instrumento de planeamento territorial, parte integrante do Plano Diretor Municipal (PDM) em que intervieram, além da Câmara Municipal, outros organismos e com diferentes níveis de competência, nomeadamente: Assembleias Municipais (AM); Conselhos Municipais de Educação (CME); serviços locais, regionais e centrais do Ministério da Educação - Direções Regionais de Educação (DRE's); Gabinete de Estatística e Planeamento da Educação (GEPE); Comissões de Coordenação e Desenvolvimento Regional (CCDR's); e Associações de Municípios.
O processo da Carta Educativa passou por cinco (5) fases (Figura 1): elaboração, aprovação; homologação; concretização e monitorização. Ao longo de todo o processo, a competência para a tomada das decisões é, quase sempre, da Câmara Municipal: durante a $1 .^{\mathrm{a}} \mathrm{e}$ $2^{\mathrm{a}}$ fases foi a entidade a quem competiu elaborar a Carta Educativa e que, após discussão e parecer do CME, foi aprovada pela AM respetiva. Durante este processo, coube ao Ministério da Educação, através do GEPE e das DRE's, prestar o apoio técnico necessário, disponibilizar toda a informação indispensável e suportar $50 \%$ das despesas inerentes à fase de elaboração. Não obstante o apoio técnico institucional disponibilizado, muitos municípios recorreram à contratação, em regime de outsourcing, de equipas técnicas qualificadas para esse efeito. Posteriormente, e ultrapassadas as duas primeiras fases, a Carta Educativa ficava sujeita à homologação governamental (3. ${ }^{\mathrm{a}}$ fase) para poder passar às fases de concretização e monitorização $\left(4 .^{\mathrm{a}}\right.$ e $5 .^{\mathrm{a}}$ fases) que deveriam ser assumidas, em termos de competência, pelos municípios.

Conceptualizada como um documento estratégico para racionalizar, redimensionar e incrementar a qualificação dos estabelecimentos de ensino que compõem a rede escolar municipal, a Carta Educativa assentava num quadro de inteligibilidade do planeamento e gestão dos estabelecimentos de ensino que em teoria se deveria afastar dos modelos utilizados ao longo das primeiras sete décadas do século XX. Sublinham-se alguns dos aspetos que, conceptualmente, sinalizam a importância e o caráter inovador deste instrumento de planeamento, ao: (i) corporizar uma visão prospetiva e integradora das dinâmicas dos territórios geográficos, sociais e educativos que compõem o município; (ii) apoiar-se num sistema flexível de soluções capaz
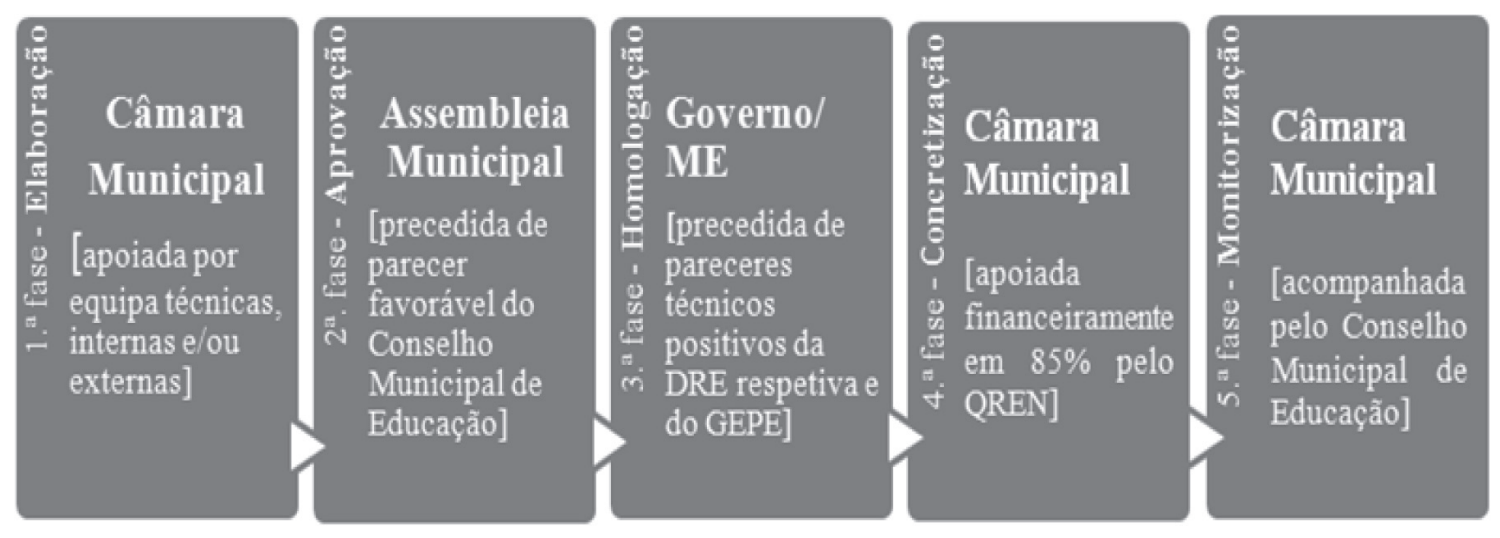

Figura 1

Fases e entidades envolvidas ao longo do processo da Carta educativa 
de servir e patrocinar as diferentes respostas nos níveis infra e intermunicipal; (iii) materializar a importância da participação dos atores locais na construção das propostas e na tomada de decisão; (iv) promover o envolvimento de equipas de planeamento (Universidades, empresas, técnicos municipais, etc.), exteriores à estrutura institucional do Ministério da Educação; (v) remeter o Estado a um papel de regulador e cofinanciador da rede escolar; (vi) fomentar a necessidade de monitorização periódica.

A Carta Educativa ao materializar-se como lugar de aprofundamento da territorialização da educação, num esforço de cruzamento e análise de um conjunto de medidas afirmadas na atribuição de competências ao poder local e às comunidades (Figura 1), permite vivenciar e evidenciar as vantagens técnicas e políticas inerentes à descentralização (FormosınHo, 2005). As vantagens técnicas resultam de uma maior adequação, rigor e celeridade da decisão: minimização da distância entre os problemas e os decisores, adaptação do ritmo e o tipo de implementação ao contexto local, aproximação entre as decisões e as pessoas a quem se aplica a decisão e a prestação de contas pelos resultados, através de mecanismos de controlo inseridos no contexto. Já as vantagens políticas da descentralização situam-se ao nível da participação e influência dos cidadãos nas decisões locais quando, ao nível do equilíbrio dos poderes, se respeitam os direitos e liberdades locais.

Tem sido possível constatar que a materialização das Cartas Educativas resultou de um processo compósito e não linear de construção local, que foi manifestamente politizado e sujeito a lógicas e tensões resultantes dos múltiplos interesses e ações dos atores envolvidos, aliás como foi referido pelas diferentes equipas envolvidas (Martins et al., 2011; Martins e CordelRo, 2011). Concomitantemente, a Carta Educativa, dadas as características conceptuais, contextuais e processuais que the estão inerentes, configura um objeto de estudo de relevante interesse, mas que foi, até ao momento, pouco investigado.

As dinâmicas políticas e comunitárias na construção da Carta Educativa, a diversidade de soluções de reorganização da rede escolar, o diferenciado papel dos Conselhos Municipais de Educação e as lógicas políticas observadas nas Assembleias Municipais aquando da legitimação final das decisões, bem como os processos de influência e negociação entre os municípios e a tutela, constituem-se como dimensões centrais na nossa investigação. Os resultados da análise destas dimensões favorecem o aprofundamento da compreensão do processo de reorganização e requalificação da rede escolar, em curso, em Portugal, como abre uma nova lente de análise sobre a territorialização educativa e os seus modos de regulação. Inserido num conjunto mais vasto de trabalhos (Martins et al., 2011; Martins e Cordeiro, 2011; Cordeiro e Martins, in press), este artigo dedica-se, no essencial, à análise da fase de elaboração da Carta Educativa, na qual se definem as estratégias de reorganização da rede educativa e as tendências de mudança. Tendo em conta que a elaboração das Cartas Educativas por diferentes equipas de trabalho, com diferentes perspetivas e abordagens na forma de desenvolver estes estudos, bem como o fato de cada uma delas ser influenciadas por lógicas políticas e comunitárias locais, estes diferentes fatores imprimiram, como seria de esperar, características diferenciadoras às propostas de reorganização e requalificação da rede escolar municipal.

\section{Dinâmicas demográficas e a procura e oferta escolares}

A partir dos finais da década de $50^{3}$ do século $X X$, a evolução do sistema educativo português (MARtins, 1968; Gomes et al., 1988; Carvalho, 1994; Candeias, 2004) foi marcado por uma "forte expansão" do número de estabelecimentos de ensino (FonseCA, 1981, p.119), com o objetivo de o dimensionar e de o adequar ao número, quase sempre, crescente de alunos (RodRIGUES, 2010). O debate do atraso 4 educacional do país (SANTOS, 1990; ReIs, 1993; BARRETo, 1996) retomado nos anos 60 veio a conduzir, não só, à expansão da rede escolar, como também a outras transformações quantitativas: aumentou o número de anos de escolarização obrigatória, o número de alunos acolhidos no sistema de ensino e o número de professores (Formosinho e MACHAdo, 2008). Os efeitos da intensa massificação escolar (PIRES, 1988)

${ }^{3}$ Em 1959, Portugal participa com um relatório próprio no chamado Projeto Regional do Mediterrâneo (TEODORo, 2000) - consiste no estudo das necessidades nacionais de educação até 1975 , com estimativas dos correspondentes encargos financeiros, tendo em atenção a possível evolução demográfica, económica e cultural de cada um dos seis países participantes no programa da OCDE para o Mediterrâneo (Espanha, Grécia Itália, Yugoslávia, Portugal e Turquia - abrindo assim o planeamento da educação à consultoria exterior. Nesse relatório procede-se à elaboração da Análise Quantitativa da Estrutura Escolar Portuguesa (1950-59), tendo em vista a preparação de pessoas qualificadas requeridas pela dinâmica da economia. $O$ documento fornece uma imagem das clamorosas carências, distorções e atrasos do sistema educativo. A descrição quantitativa da estrutura escolar no decénio de 50, e a sua previsível e desejável evolução até 1975 , vem a ser publicada apenas em Abril de 1964, já sob a alçada de Galvão Teles (MARTINs et al.,1964).

${ }^{4} \mathrm{Em} \mathrm{1960}$, tendo por base o Censo da população, existiam em Portugal $40 \%$ de analfabetos, com uma taxa superior nas mulheres. Esse valor vem descendo até ao penúltimo momento censitário (2001), cuja taxa era de $9 \%$, sendo $12 \%$ nas mulheres (o INE ainda não disponibilizou esta informação relativamente aos censos 2011). 
que exigia soluções urgentes e vultuosas traduziram-se num significativo alargamento da rede escolar, principalmente, nos graus pré-escolar, "preparatório" (atual $2^{\circ}$ ciclo) e secundário. Situação que conduziu a "uma diminuição do peso dos distritos de Lisboa e Porto no conjunto do país, em termos de alunos matriculados naqueles mesmos graus e dos respetivos estabelecimentos" (FonseCA, 1981, p. 120).

Mas, até 1974, a expansão da rede continua a ser conduzida de maneira espontaneista e de acordo com critérios de tipo administrativo: escolas primárias nas freguesias, escolas preparatórias nas sedes de concelho, liceus e escolas técnicas nos distritos (BARroso, 1992, p. 86). O excedente constituía, manifestamente, exceção.

Durante os períodos de incremento da mobilização educativa e de normalização democrática ${ }^{5}$ (GRÁcIO, 1981, 1986; Stoer, 1986; Stoer et al., 1990; Teodoro, 2001), que vieram a ocorrer entre a "revolução do 25 de Abril" e a aprovação da LBSE, em 1986, regista-se um esforço do Estado em aumentar o número de estabelecimentos de ensino do $2^{\circ}$ e $3^{\circ}$ ciclo (GEPE/INE, 2009b) face às metas políticas definidas para a educação: cumprimento da escolaridade de 6 anos, unificação do secundário e a expansão das taxas de frequência. Não obstante, durante esse período, os inventários de carências eram "produzidos centralmente, desinseridos do contexto local" e os planos de execução "eram amiudadas vezes alterados por critérios políticos, por força de pressões locais, por falta de verbas e terrenos, por necessidade de corrigir prioridades mal elaboradas, etc." (BARroso, 1992, p.86). Consequências do centralismo burocrático como forma de governo de educação (Formosinho, 2005; Lima, 2007), cuja incapacidade dos serviços centrais preverem com exatidão todos os problemas que surgirão ao nível local é uma das suas principais desvantagens.

A reforma educativa que precedeu a LBSE, mantinha preocupações com a expansão da rede escolar face aos desafios colocados pela introdução da escolaridade obrigatória de 9 anos (CRSE, 1988; TEODORO, 1993; 2001; Nóvos e d'ó, 2007). Mas a necessidade de continuar a construção de estabelecimentos de ensino é acompanhada, a partir do final dos anos 80, por novos Critérios de Planeamento da Rede Escolar (Despacho conjunto

${ }^{5}$ Para Stephen Stoer a 'normalização' da educação em Portugal, após o período revolucionário, foi principalmente um processo pelo qual o Estado reconquistou e reassumiu o controle da educação, definindo e limitando aquilo que poderia considerar-se como educação. Todo o sistema de ensino foi atingido por esse processo de definição e limitação que foi impulsionada pelo desejo de substituir a política pelo planeamento (Stoer, 1986, p. 64).
28/SERE/SEAM/88) que vieram a estabelecer normas orientadoras para racionalização da rede $\left(1^{\circ} \mathrm{ciclo}\right) \mathrm{e}$ adaptação do parque escolar aos princípios dimanados da LBSE (ME, 1990). Os princípios de diversidade, complementaridade e flexibilidade dos equipamentos vieram alargar a oferta de tipologias de modo a responder às diversas realidades regionais, quer demográficas, quer socioeconómicas.

Durante os anos 90, assiste-se à diversificação das tipologias identificadas por Eurico Lemos PIREs (1987, p. 37-39), situação que passaria a conferir, segundo LIMA (2004, p. 9) "uma considerável flexibilidade" à rede escolar. Medidas como a das Escolas Básicas Integradas ${ }^{6}$ (Pires, 1993; Amiguinho et al., 1998; Neto-Mendes, 1995) e os Territórios Educativos de Intervenção Prioritária TEIP - (CosTA et al., 2001, p. 15-17) inserem-se nesta lógica de flexibilização e reconfiguração da rede de escolas. Também as ideias de descentralização, participação e os inerentes apelos aos dinamismos locais que acompanham a LBSE fazem catapultar a necessidade de um novo modelo planeamento da rede escolar prospetivo e territorializado que até 2003 teve muita dificuldade em se impor.

No início do século XXI, as preocupações dominantes sobre a rede escolar prendem-se com questões de reorganização e qualidade dos equipamentos; descentralização do planeamento e da sua gestão; e adequação às dinâmicas demográficas (devendo registar-se as significativas alterações e evoluções que vieram a verificar-se entre os sectores de alta e baixa densidades do território nacional).

\subsection{Dinâmicas demográficas}

Em termos de relação entre a expansão da rede escolar e as questões demográficas do país parece apresentar-se, embora apenas aparentemente, algo contraditórias com a evolução observada em termos de dinâmicas demográficas, ao longo do último meio século.

É inquestionável, a este nível, que se observou, por um lado, uma redução do ritmo de crescimento da população e uma significativa quebra da natalidade, fatos que se refletiram na estrutura demográfica do país entre 1950 e 2001 (MARTIns et al., 2011; Cordeiro et al., in press), o mesmo se verificando com um reforço da clara dicotomia existente entre o litoral e o interior (ou mesmo do reforço da diferença entre os setores de baixa e alta densidades). Estes fatos introduziram

${ }^{6}$ Despacho Conjunto n. ${ }^{\circ}$ 19/SERE/SEAM/90. O conceito de EBI consagrado é aquele que corresponde a uma escola que inclua os nove anos de escolaridade obrigatória, abrangendo, assim, os $1 .^{\circ}, 2 .^{\circ}$ e $3 .^{\circ} \mathrm{Ci}$ clos, e, sempre que possível, os Jardins-de-infância. 
inevitavelmente ritmos e consequências em termos de crescimento da demografia escolar, os quais foram diametralmente opostos.

Até à instauração da democracia, em 1974, o crescimento da população portuguesa foi sendo negativo, resultado de uma forte emigração da década de 60 , o que introduziu a quebra da natalidade como um dos seus principais marcadores. Já perto do final da década de 70 assiste-se a um ligeiro aumento da população relacionado, em grande parte, com o retorno de cidadãos associado à descolonização, observando-se, no entanto, que os anos 80 foram novamente marcados pela desaceleração do crescimento populacional, provocada pela quebra de natalidade e por um saldo migratório negativo.

Apesar do maior dinamismo demográfico verificado no início da década de 90 , em face dos movimentos imigratórios e da ligeira recuperação da natalidade, a primeira década do século XXI é marcada por uma taxa de crescimento natural praticamente nula, embora nos censos de 2011 se tenha observado um ligeiro crescimento relativamente ao Censos de 2001 (MARTINs et al., 2011; CORDEIRO et al., in press).

\subsection{Dinâmicas da procura e oferta escolares (1960-2010)}

Em termos educativos, ao longo do último meio século, assistiu-se à aposta, por sucessivos governos, no progressivo alargamento da escolaridade obrigatória: em 1964 a escolaridade obrigatória era de apenas 6 anos; em 1973 passa para 8 anos; em 1986, com a aprovação da LBSE, a escolaridade obrigatória alarga-se até ao $9^{\circ}$ ano. Já em pleno século XXI, mais concretamente em 2009, é aprovado o alargamento da escolaridade obrigatória para 12 anos e a universalidade da educação pré-escolar a partir dos cinco anos de idade (Lei n. 85/2009, de 27 de Agosto). Os sucessivos alargamentos da escolaridade obrigatória levaram ao crescimento do número de estabelecimento de ensino e vieram criar novos padrões de procura escolar.

\section{A procura escolar}

A opção pelo incremento da escolarização das crianças, dos adolescentes e dos jovens conduziu à massificação escolar (PIREs, 1988; 2000), situação que obrigou o Estado a criar condições para acolher e dar aulas a mais alunos (Formosinho e Machado, 2008, p.6), em consequência do registado aumento da procura escolar.

No ano letivo $1960 / 61,98,2 \%$ do total dos alunos matriculados frequentavam o ensino básico, principalmente o $1^{\circ}$ ciclo. Neste ano, os alunos a frequentar a educação pré-escolar e o ensino secundário correspondiam apenas a $0,6 \%$ e $1,2 \%$, respetivamente, do total de matrículas. Já nos $2^{\circ}$ e $3^{\circ}$ ciclo não chegava aos $8,0 \%$ (7,5\% e $6,1 \%)$. Situação que se veio a alterar profundamente nas décadas seguintes (Figura 5$)^{7}$.

Entre 1960 e 2010 o aumento da procura (GEPE/ INE, 2009a) regista-se, em particular, na educação préescolar e no $2^{\circ}, 3^{\circ}$ ciclo e ensino secundário (Figura 5). Pelo contrário, no caso do $1{ }^{\circ}$ ciclo, e durante o mesmo período em análise, é o único sector que perde continuadamente alunos, especialmente a partir de meados da década de 80 (Figura 5), situação que reflete tudo o que foi já referido em termos da evolução demográfica do país. É possível observar (Figura 5) que entre o ano letivo de 1960/61 (984.084 alunos) e o ano letivo de 2009/2010 (1.581.049 alunos) a procura no sistema educativo público cresceu, globalmente, perto de seiscentos mil alunos. 0 valor mais elevado da procura ocorreu no ano letivo de 1991/92, em que duplicou a verificada no início da década de 60 , com cerca de dois milhões de alunos matriculados (Figura 5).

Mas, a partir da década de 90 , a dinâmica da população escolar passou a ser comandada pela diminuição da taxa de crescimento natural da população após se ter desvanecido o efeito da aplicação da Lei de Sistema Educativo de 1986, que regulamentou a escolaridade obrigatória de nove anos. Só nos últimos dez anos, o ensino público perdeu mais de 135 mil alunos, do pré-escolar ao ensino secundário (GEPE/INE, 2009a; ME, 2011b).

Através de um olhar mais detalhado é observável que, apesar do aumento global verificado da procura escolar, a evolução apresenta variações diferenciadas ao longo do tempo, assim como não é homogénea nos diferentes níveis de ensino em presença. Nas décadas de 60 e 70 observa-se um aumento global da procura, com especial incidência no $2 .^{\circ}$ e $3 .^{\circ}$ ciclo (GEPE/INE, 2009a). A partir de 1985 regista-se uma progressiva diminuição da procura no $1^{\circ} \mathrm{e} 2 .^{\circ}$ ciclo do ensino básico, em que cada um perde, respetivamente 50 , \% e $34 \%$. Dez anos mais tarde (1995/1996), a tendência de diminuição da população escolar alastra-se ao $30^{\circ}$ ciclo e ensino secundário até $2006 / 2007$, data a partir da qual há uma ligeira recuperação ${ }^{8}$. Apesar da perda de alunos assinalada, regista-se no início do século XXI (2000/01)

${ }^{7}$ A educação pré-escolar e o ensino secundário com taxas reais de escolarização de aproximadamente $1 \%$, em 1960, vieram a atingir, respetivamente, $83,9 \%$ e $71,4 \%$ em 2010 (ME, 2011b, p. 27). A cobertura integral das crianças do $1^{\circ}$ ciclo do ensino básico verifica-se desde 1980 .

${ }^{8}$ Estes acréscimos foram fundamentalmente determinados pelas inscrições de adultos no $3^{\circ}$ ciclo do ensino básico e ensino secundário especialmente no âmbito do Sistema de Reconhecimento, Validação e Certificação de Competências (SRVCC). 


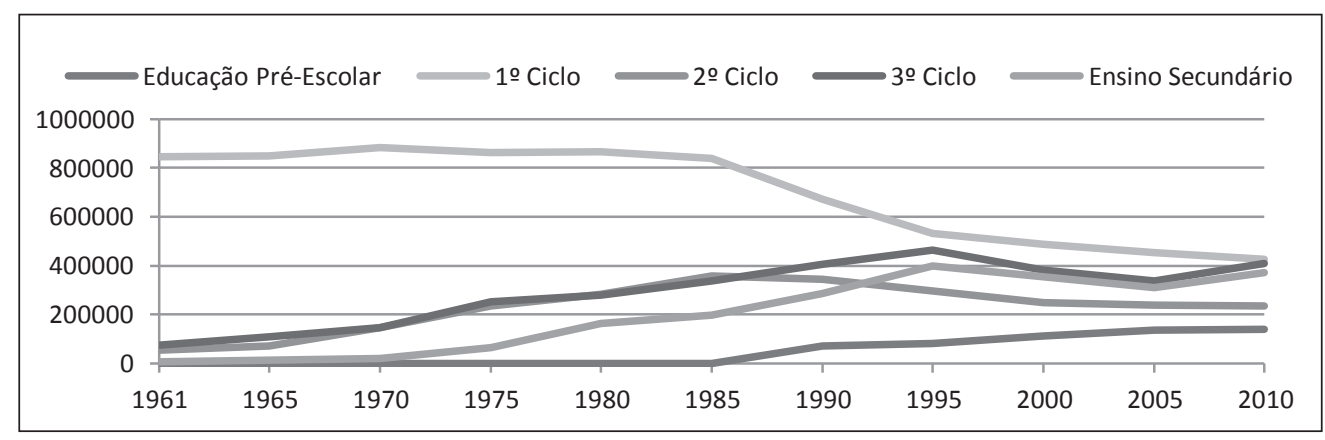

Figura 5

Evolução dos alunos matriculados no ensino público (1960 a 2010)

Fonte: Dados com base em ME/PORDATA

uma taxa de escolarização no $2^{\circ}$ e $3^{\circ}$ ciclo aproxima dos $90 \%$ e no ensino secundário de $62,5 \%$, valores que têm vindo a evoluir positivamente.

A educação pré-escolar é o único sector onde se observa um contínuo aumento da procura que, não sendo obrigatória, foi muito significativa nos últimos vinte anos: em 1990/1991 a quota do ensino público em termos de alunos inscritos era na ordem de $44,0 \%$ e, em $2009 / 2010$, esta proporção era de cerca de $51,0 \%$, ultrapassando em número de alunos que estavam matriculados no ensino privado.

\section{A oferta escolar}

Para fazer face ao aumento da procura escolar verificada, a partir dos anos 70 , no $2 .^{\circ}, 3 .^{\circ}$ ciclos e, nos anos 90, no ensino secundário e na educação préescolar, o Estado apostou na construção de novas escolas e jardins-de-infância que redundou no aumento da capacidade de oferta por região e município e na diversidade e flexibilidade de tipologias. Em movimen- to contrário, assiste-se, a partir da década de 60, a uma diminuição expressiva do número de estabelecimentos do $1{ }^{\circ}$ ciclo do ensino básico (Figura 6).

No ano letivo 1960/61 a rede escolar era constituída por um total de 17506 estabelecimentos de ensino do $1{ }^{\circ} \mathrm{ciclo}$, ensino básico e secundário, sendo que os estabelecimentos do $2^{\circ}, 3^{\circ}$ ciclo e secundário representavam apenas 1,48\% da rede (GEPE/INE, 2009b: 263-264). Esta situação veio a modificar-se, profundamente, a partir da década de 70.

0 investimento em infraestruturas educativas, nas décadas seguintes, foi predominantemente orientado para a construção de estabelecimentos de ensino do ensino básico ( $2^{\circ}$ e $3^{\circ}$ ciclos), jardins-de-infância, assim como em pavilhões desportivos e bibliotecas escolares. Esta aposta na construção de novos estabelecimentos de ensino tinha com objetivo principal criar as condições físicas para a expansão do sistema educativo. Essa necessidade é resultante dos desafios criados pelo alargamento da escolaridade básica e obrigatória de 9 anos

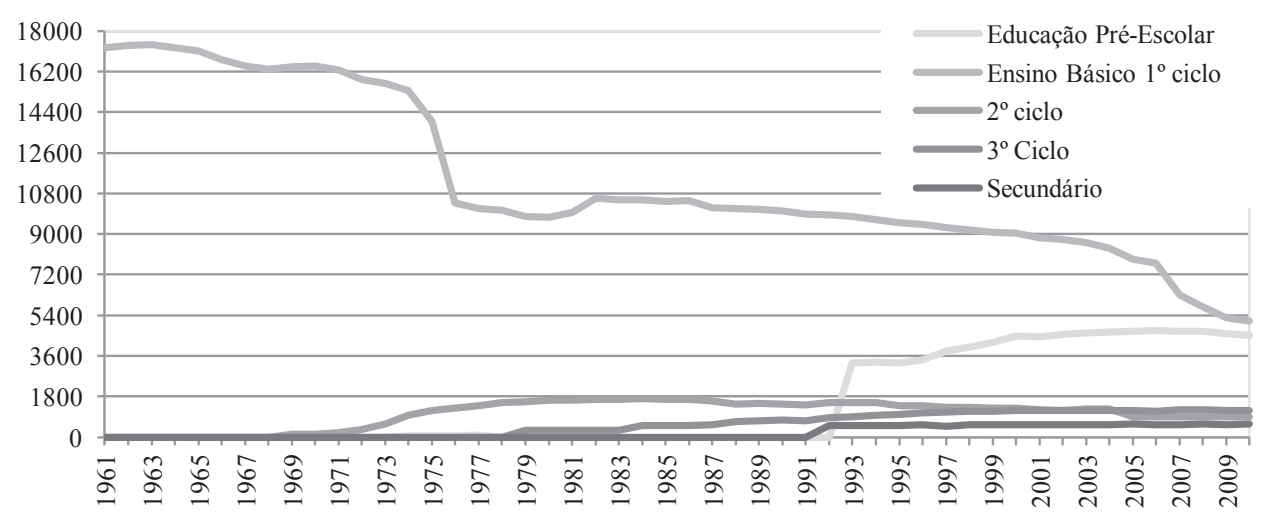

Figura 6

Evolução do número de estabelecimentos nos ensinos Pré-escolar, Básico e Secundário (1960-2010)

Fonte: Dados com base em ME/PORDATA 
e da expansão da rede de jardim-de-infância a todo o território nacional (Rodrigues, 2010).

$\mathrm{Na}$ década de 90 verifica-se uma notável expansão ${ }^{9}$ na rede de jardins-de-infância: no ano lectivo 1973/74 existiam apenas 54 jardins-de-infância, em vinte e cinco anos a rede cresceu para 4525 estabelecimentos. No caso do $1{ }^{\circ}$ ciclo, o movimento é contrário: durante as últimas cinco décadas este sector de ensino perde $70 \%$ dos estabelecimentos (de 17250 escolas em 1961 para 5151 em 2010). O encerramento de milhares de escolas do $1^{\circ}$ ciclo tem sido contrabalançado com a construção de novos estabelecimentos: destacam-se as do Projecto Normalizado de Escolas Primárias, também designado por P3, construídas nos anos 80 (ME, 2011a); as Escolas Básicas Integradas (PIREs, 1993; Neto-Mendes, 1995) nos anos 90 e os centros escolares, edificados durante na primeira década do século XXI (RodRIGUes, 2010).

\section{Reorganização e qualificação da rede escolar (1998-2011)}

Apesar dos progressos registados até aos anos 90 do século $X X$, o carácter pontual das acções ${ }^{10}$ empreendidas pelo Estado, no caso das Escolas Secundárias (ES), e pelos Municípios, no caso das escolas do $1^{\circ} \mathrm{Ciclo}$ (EB1), não permitiu uma requalificação abrangente do parque escolar, que, na maioria dos casos, denotava sinais vários de desqualificação física, ambiental e funcional.

Durante a década de 90 , a par do estado de degradação de muitos estabelecimentos de ensino, os efeitos da retração da procura escolar e das tendências de "litoralização e urbanização" da população portuguesa agravam-se: escolas a "mais" em zonas de baixa

\footnotetext{
${ }^{9}$ Isso veio a verificar-se após a publicação da Lei n. ${ }^{\circ}$ 5/97, de 10 de Fevereiro e do Decreto-Lei n.0 147/97, de 11 de Junho.

${ }^{10}$ As intervencõos corretivas e as adaptações e melhoramentos na rede escolar, entretanto efetuados, processaram-se, na maior parte dos casos, de forma isolada, pontual e sem uma visão sistémica e prospetiva. Era visível, em ambos os casos, a falta de uma prática constante e consistente, quer ao nível da conservação e manutenção dos edifícios existentes, em função do desgaste provocado pelo uso e aos problemas construtivos a que os edifícios estão sujeitos, quer ao nível da sua adaptacão funcional das alteracões entretanto ocorridas em termos dos curricula e das práticas educativas e formativas. Mas os problemas da rede escolar do $1^{\circ}$ Ciclo do Ensino Básico não se circunscreviam aos défices infraestruturais dos edifícios (FormosinHo, 1998; ANíBal, 1999). O gigantismo da rede e a sua dispersão territorial (NóVOA, 1988; PIMENTA 2006), a idade avançada de muitos equipamentos educativos associados à falta de investimento manutenção por parte dos Municípios e do Estado Central, à prevalência de escolas de pequena escala (uma ou duas salas), à sobrelotação e falta de vagas nas zonas urbanas, o lento e tardio processo de territorialização da educação (Fernandes, 2004) e à ineficácia do uso planeamento estático, centralizado e burocratizado, foram fatores que contribuíram que a sua resolução viesse a ser tardia.
}

densidade e escolas e vagas a "menos" nas zonas de alta densidade. Estes problemas não permitiam o cumprimento do proposto.

Em face destes problemas estruturais, a prioridade, no final dos anos 90, já não é a expansão e diversificação da rede escolar, mas a sua reorganização e modernização. Motivado pela forte regressão da demografia escolar e pelos desafios colocados pelas reformas educativas (administrativa e curricular), o repto que se coloca às políticas de rede escolar passa a ser a descentralização efetiva do seu planeamento e gestão, a sua requalificação e a constituição de redes de escolas agregadas em unidades de gestão.

Sob os efeitos dos paradigmas do planeamento estratégico, da qualidade, de uma gestão mais eficiente e eficaz (New Public Management) e da territorialização educativa assiste-se, a partir de 1998, à desconstrução de uma rede escolar pública única, de natureza estadocêntrica, para a (re)construção de "redes escolares" municipais policêntricas (planeadas, constituídas, geridas e administradas localmente, mas reguladas pelo Estado central). A configuração dessas "redes" conhece desenvolvimentos expressivos através da operacionalização de dois instrumentos conceptuais: os agrupamentos de escolas (1998) e, posteriormente, as Cartas Educativas (2003)

\subsection{Agrupamentos de escolas como instrumento de reorganização administrativa}

Os agrupamentos de escolas ${ }^{11}$, previstos desde a Lei de Bases do Sistema Educativo (art. ${ }^{\circ} 40 .^{\circ}$ e $45 .^{\circ}$ ), como referem FormosinHo (1988) e LIMA (2004), foram criados em 1998, embora a sua constituição tenha sido precedida por uma fase experimental ${ }^{12}$. A concretização da constituição dos agrupamentos de escolas permitiu, pela primeira vez, agregação de escolas (Lima, 2004, 2006) através de um reordenamento da rede es-

11 O agrupamento de escolas é uma unidade organizacional, dotada de órgãos próprios de administração e gestão, constituída por estabelecimentos de educação pré--escolar e escolas de um ou mais níveis e ciclos de ensino, com vista à realização das finalidades seguintes: a) Proporcionar um percurso sequencial e articulado dos alunos abrangidos numa dada área geográfica e favorecer a transição adequada entre níveis e ciclos de ensino; b) Superar situações de isolamento de escolas e estabelecimentos de educação pré-escolar e prevenir a exclusão social e escolar; c) Reforcar a capacidade pedagógica das escolas e estabelecimentos de educação pré -escolar que o integram e realizar a gestão racional dos recursos; d) Garantir o funcionamento de um regime de autonomia, administração e gestão ( art $^{\circ} 6$ do decreto-Lei 75/2008 de 22 de Abril).

12 Licínio Lima (2004: 17) recorda que o Despacho Normativo n. ${ }^{\circ}$ 27/97 (ponto 1) veio consagrar um período experimental (1997/1998) de constituição de agrupamentos, cujo objetivo era o de "preparação da aplicação de um novo regime de autonomia e gestão das escolas", desig nadamente, em termos de "reordenamento da rede escolar, através da apresentação de propostas de associação ou agrupamentos de escolas, bem como do desenvolvimento dos respetivos projetos educativos e regulamentos internos". 
colar de base político-administrativa e com critérios gestionários e autonómicos, cujas soluções organizacionais assentam em duas lógicas: a lógica associativaautonómica e a lógica racionalizadora-centralizadora (LIMA, 2011).

O seu desenvolvimento, amplitude e configuração desenvolvem-se ao longo de três fases: $1^{\text {a }}$ fase (1998-2003); $2^{\text {a }}$ fase (2003-2008); $3^{\text {a }}$ fase (a partir de 2008). Durante a primeira fase, a constituição de agrupamentos de escolas deixa em aberto a opção pela lógica horizontal ou vertical, mas privilegia o agrupamento de jardins-de-infância e escolas do $1 .{ }^{\circ} \mathrm{Ciclo}$, "procurando resolver o seu possível isolamento e a sua eventual falta de dimensão" (Lima, 2004; 2006). Em 2003, o XV Governo Constitucional dá início à segunda fase para a qual são definidas duas prioridades: concretizar o agrupamento de todas as escolas do continente português (objetivo por concretizar); privilegiar como modelo os agrupamentos verticais de escolas (os agrupamentos horizontais passam a ser exceção, quando "devidamente fundamentados pelo diretor regional de educação respetivo" (Despacho n. 13313/2003). Ultrapassada a generalização dos agrupamentos verticais ao território nacional, a terceira fase, que situamos a partir de 2008, caracteriza-se pela agregação de agrupamentos e que se concretiza através de um processo de fusão e/ou pelo aprofundamento final da verticalização, ao passar a incluir como topo as escolas secundárias.

\subsection{Carta Educativa: instrumento estratégico e de mudança}

Depois de uma tentativa falhada ${ }^{13}$ da Carta Escolar, a Carta Educativa, consagrada legalmente em $2003^{14}$, viria a constituir-se como instrumento de mu-

${ }^{13}$ A Lei n. ${ }^{\circ} 159 / 99$ de 14 de Setembro, no âmbito das transferências de competências educativas para os municípios, atribui-lhes poderes, pela primeira vez, no domínio do planeamento da rede escolar. Os municípios passam a ser responsáveis por elaborarem a Carta Escolar (art. $\left.{ }^{\circ} 19\right)$. A falta de regulamentação, financiamento e vontade política levaram a que fossem muito poucos os municípios a elaborarem este instrumento de planeamento. Situação que se veio a verificar muito idêntica relativamente à constituição dos Conselhos Locais de Educação.

${ }^{14}$ Quando as Cartas Educativas foram lançadas (2003), a rede escolar continuava confrontada com muitos dos problemas que a caracterizaram durante última metade do século $X X$, em especial, no que diz respeito ao $1^{\circ}$ Ciclo: a existência de uma densa rede de escolas "primárias" desajustada às "transformações demográficas e de acessibilidade observadas nas últimas décadas" (Cordeiro, 2011); problemas graves de manutenção e governabilidade; do ponto de vista pedagógico e educativo as escolas do $1^{\circ}$ Ciclo apresentavam-se, na grande maioria dos casos, profundamente obsoletas face às novas exigências de aprendizagem e de resposta social (escolas com um número reduzido de alunos; problemas ao nível dos sistemas de aquecimento; materiais pedagógicos débeis; inexistência de espaços para a prática desportiva, atividade de leitura, refeições, entre outros). dança $^{15}$ conceptual, metodológico e das políticas de definição e gestão da rede de escolas do $1^{\circ}$ Ciclo e educação pré-escolar. Essas mudanças são assinaladas em dois planos principais: (i) ao nível do planeamento da rede educativa a nível municipal, através da consagração do planeamento estratégico (prospetivo, interativo e de base territorial municipal) como estratégia a seguir; (ii) ao nível da valorização da participação dos municípios, através da intervenção de vários órgãos municipais (executivo municipal; assembleia municipal e conselho municipal de educação) na definição preponderante das políticas de planeamento e reorganização da rede educativa municipal.

Entre outros aspetos, clarificou competências a exercer neste âmbito pelas autarquias locais e associou a estas competências processos de atuação e parceria, instrumentos de formalização destes processos, estruturas orgânicas (Conselho Municipal de Educação e Assembleia Municipal) e meios adequados (apoio técnico e financeiro). Isso foi conseguido, no plano normativo, através da regulamentação das competências na área da realização de investimentos por parte dos municípios, nos domínios da construção, apetrechamento e manutenção dos estabelecimentos da educação pré-escolar e do ensino básico ${ }^{16}$. No plano político, a celebração de vários protocolos de compromisso entre o Ministério da Educação e a Associação Nacional de Municípios relativos ao desenvolvimento do processo de elaboração e concretização da Carta Educativa e a disponibilização de um programa de apoio financeiro para a efetivar a reorganização e requalificação da rede, funcionaram como "alavancas" para o desenrolar do processo (MATTHEws et al., 2009; RodRIGUes, 2010).

$\mathrm{O}$ encerramento de milhares de escolas do $1^{\circ} \mathrm{Ci}$ clo (frequentadas por menos de 10 e 20 alunos) pelo Ministério da Educação, os desafios colocados pelo funcionamento da "Escola a Tempo Inteiro", e a necessidade de acesso ao financiamento para a ampliação ou construção de novas escolas, foram os fatores que condicionaram e mobilizaram os municípios para o desenvolvimento da Carta Educativa.

${ }^{15}$ Os fundamentos que suportam a Carta Educativa prevêem, simultaneamente, a rejeição, quer do planeamento tradicional ou compreensivo, de carácter centralizado, burocrático, assente em soluções uniformes, neutras, racionais e replicáveis que sustentou o plano de construções escolares executado, em Portugal, desde a década de 30 do século XX (o Plano dos Centenários é o exemplo, por excelência, desse tipo de planeamento), quer da conceção da participação dos municípios remetida a um mero serviço periférico de apoio à educação (Fernandes, 2004).

${ }^{16} \mathrm{O}$ exercício das competências previstas ao nível dos investimentos na construção, apetrechamento e manutenção dos estabelecimentos dos $2^{\circ}$ e $3^{\circ}$ ciclos do ensino básico, está dependente de celebração de contrato entre o Ministério da Educação e os municípios, assente na identificação padronizada de tipologias e custos (Artigo 22. ${ }^{\circ}$ do Decreto-lei n. ${ }^{\circ}$ 7/2003, de 15 de Janeiro de 2003). 
O nível de compromisso variou consoante o município: se por um lado, houve municípios que viram neste instrumento "uma janela de oportunidades" para resolver os problemas há muito reivindicados, por outro, registaram-se casos em que foram "empurrados" pelas "circunstâncias": a falta de espaços e condições para acolher os alunos das escolas encerradas e o acesso ao financiamento estar condicionado à aprovação da Carta Educativa acabou por minimizar as resistências desses municípios. No entanto, há a assinalar que o maior ou menor grau de mobilização foi também ele condicionado pelos problemas intrínsecos e extrínsecos inerentes ao encerramento de escolas, entre os quais se encontra a dificuldade de encontrar consensos políticos e comunitários face às resistências ou mesmo oposições locais.

\subsection{Desenvolvimento das Cartas educativas}

A partir de 2005 desenvolve-se um intenso processo de elaboração, aprovação e homologação das Cartas Educativas que se conclui em 2010 (em Outubro de 2006 são homologadas as primeiras 38 Cartas Educativas).

Em 2007, o Ministério da Educação lança o Programa Nacional de Requalificação da Rede do $1^{\circ} \mathrm{Ciclo}$ do Ensino Básico e da Educação Pré-escolar que visa garantir a igualdade de oportunidades de acesso a espaços educativos com a dimensão e os recursos adequados ao sucesso educativo. 0 programa tem como objetivos investir em escolas com mais do que um nível de ensino - centro escolar ${ }^{17}$-, aumentar o número de alunos por escola, criar condições para que os estabelecimentos funcionem em regime normal e eliminar os edifícios de construção precária (ME, 2007). Este programa viria a ser acompanhado por um regulamento ${ }^{18}$ que veio estabelecer o regime específico de aplicação dos apoios a conceder no âmbito do $P O$ Regional $X X$, por forma a criar condições de concretização das soluções previstas nas Cartas Educativas.

O Ministério da Educação disponibilizou aos municípios, através do QREN 2007-2013, 400 milhões de euros do Fundo Social Europeu para a construção de

${ }^{17}$ Os centros escolares "são estabelecimentos de ensino que reúnem crianças do $1^{\circ}$ ciclo e, frequentemente, do jardim-de-infância. Estes centros permitiram congregar crianças dispersas por escolas de pequena dimensão, proporcionando melhores condições de ensino aos professores (...) e de aprendizagem aos alunos. Os centros escolares criados de raiz ou modernizados pelas autarquias, com financiamento comunitário, além das salas de aula, incluem espaços de trabalho para os professores, bibliotecas, refeitórios, locais para a prática desportiva e equipamentos informáticos de última geração" (ME, 2001c, p. 6)

${ }^{18}$ O Regulamento Específico Requalificação da Rede Escolar de $1^{\circ}$ Ciclo do Ensino Básico e da Educação Pré-Escolar foi aprovado pela Comissão Ministerial de Coordenação dos PO Regionais em 19/03/2008. centros escolares e requalificação de escolas do $1^{\circ} \mathrm{ciclo}$ e jardins-de-infância. Os apoios atribuídos pelo programa operacional variaram entre $50 \%$ e $80 \%$. Entre as despesas consideradas elegíveis para constar na proposta de intervenção, contam-se não só as obras de construção, de ampliação e de requalificação dos edifícios, mas também os arranjos exteriores dentro do perímetro dos estabelecimentos e, ainda, o investimento em mobiliário escolar, material didático e equipamento informático. Para operacionalizar o acesso ao financiamento por parte dos municípios, o Ministério da Educação criou, em Dezembro de 2007, a Plataforma Informática de Monitorização da Requalificação da Rede Escolar do Ensino Básico e da Educação Pré-Escolar, a qual permitiu aos municípios submeter os projetos que viriam a ser apreciados pelas CCDR's, após parecer favorável das DRE's e GEPE.

Embora não existam dados definitivos publicados, é possível fazer um balanço da concretização das Cartas Educativas, com destaque para a situação na região centro. Os dados globais disponibilizados pelo Ministério da Educação, para o período 2008 a 2010, referem a aprovação de financiamento para 566 Centros Escolares, com 333 concluídos e 128 em obra. Relativamente à rede de jardins-de-infância, foram aprovados 181 projetos, 28 dos quais já concluídos. Em paralelo assiste-se ao encerramento de 2800 escolas do $1^{\circ} \mathrm{Ciclo}$ e 150 jardins-de-infância.

No que respeita à região centro, para o período 2008 a 2011, a informação disponibilizada pela Comissão de Coordenação e Desenvolvimento do +Centro (engloba um total de 100 municípios) sinaliza a aprovação de 210 Centros Escolares, os quais envolvem um investimento total previsto de 355 milhões de euros, com uma comparticipação do FEDER de 219 milhões de euros.

Hoje é já possível afirmar que a rede escolar municipal (escolas do $1^{\circ}$ ciclo e jardins-de-infância) se encontra, de uma forma global, em profunda mudança, não só pelo número expressivo de escolas encerradas, mas também pela aposta na construção de novos estabelecimentos de ensino modernos e de maior dimensão e pelo volume de financiamento envolvido. Nesta mudança a Carta Educativa funcionou como um instrumento legitimador e acelerador da reorganização da rede em cada um dos municípios, ao "encontrar soluções educativas locais no contexto político nacional" (MATTHEWs et al., 2009, p. 38). Simultaneamente, a Carta Educativa procurou também responder à adequação da oferta à procura, através da passagem da "crise de problemas" para a "crise de soluções" (Formosinho et al., 2005) e da "regulação pela procura" para uma "regu- 
lação pela oferta"(BarRoso, 2003; CARDOSO, 2003). Nesta perspetiva, Rochette Cordeiro defende que a "reorganização da rede deve ser alargada aos restantes níveis de ensino básico, de modo a permitir que a otimização de recursos seja efetiva em toda a rede escolar do nosso país" (CoRdEIRO, 2011, p. 3).

\section{Construção técnica e política da carta educativa municipal: resultados de uma investigação}

Os resultados que se apresentam em seguida são uma parcela de uma investigação mais vasta sobre a regulação das Cartas Educativas, desenvolvida junto de 14 municípios da região centro entre 2009 e 2011. Apoiada numa investigação de cariz qualitativo (Afonso, 2005) e materializada por um design de investigação assente num estudo de caso múltiplo (YıN, 1984; STAKE, 1998), o estudo empírico desenvolveu-se em três planos (das orientações para a ação; das decisões; e da execução) e em três níveis (local, regional e nacional). A concretização do estudo empírico consubstanciou-se num alargado número de entrevistas a múltiplos atores (vereadores de educação; técnicos e chefes de divisões dos serviços educativos do município; elementos do Conselho Municipal de Educação, equipas técnicas responsáveis pela elaboração de Cartas Educativas; dirigentes técnicos e políticos da administração regional e central do Ministério da Educação; entre outros) e na análise documental (cartas educativas municipais; atas dos Conselhos Municipais e das Assembleias Municipais; textos legais; estatísticas oficiais, etc.) de forma a robustecer a cadeia de evidências que legitimam o projeto.

Através da análise documental das Cartas Educativas formuladas pelos catorze municípios que constituem a base de análise do nosso trabalho empírico e de um conjunto significativo de entrevistas realizadas a responsáveis municipais e elementos das equipas técnicas, procura-se caracterizar a construção técnica e política da Carta Educativa municipal. Propomo-nos, num primeiro momento, caracterizar a participação das "equipas técnicas" na elaboração das Cartas Educativas, a partir da "visão" que elas próprias detêm do processo; num segundo momento, descrever as três principais tendências de soluções de reorganização identificadas para o conjunto dos 14 municípios estudados e analisamos o grau de correspondência entre as soluções propostas e as realizadas; por último, traçar a "visão" geral que os municípios têm sobre a Carta Educativa e o seu desenvolvimento.

\subsection{Elaboração da Carta Educativa: entre a tecnicidade e as decisões políticas}

De um modo geral, a fase de elaboração da Carta Educativa é marcada por diversos passos metodológicos, circunscritos a dois momentos. No primeiro, o trabalho é essencialmente técnico. A equipa técnica tem que proceder a uma caracterização sumária da localização e organização espacial dos edifícios e equipamentos educativos, elaborar o diagnóstico estratégico, as projeções de desenvolvimento e a proposta de intervenção relativamente à rede pública. No segundo momento, predomina a componente política, (embora se registem casos onde a componente técnica está muito presente na decisão política). Cabe ao executivo municipal tomar decisões ao nível das principais medidas a adotar e a sua justificação, o programa de execução, a calendarização da concretização das medidas constantes do relatório, bem como o plano de financiamento onde constam a estimativa do custo das realizações propostas, a menção das fontes de financiamento e as entidades responsáveis pela sua execução.

Apesar dos passos metodológicos prescritos, os dados da investigação confirmam que elaboração das Cartas Educativas por diferentes equipas técnicas, com diferentes perspetivas e abordagens na forma de desenvolver estes estudos, imprimiram, como era espectável, características diferenciadoras na conceção e concretização desses projetos. No entanto, também foi possível atestar que as Cartas Educativas e respetivas propostas de reorganização da rede são, ao nível local, muito condicionadas pelas opções políticas municipais que não são alheias ao parecer emitido pelo Conselho Municipal de Educação (CME), ao escrutínio pela Assembleia Municipal (AM) e às tensões e dinâmicas comunitárias observadas.

\section{2. "Visão" das equipas técnicas}

A elaboração da Carta Educativa requer conhecimento pormenorizado do território municipal, domínio técnico e cientifico dos instrumentos de planeamento e capacidade de compaginar as soluções técnicas aos objetivos políticos e educativos traçados pelo município e pelo Ministério da Educação.

Verificou-se que os municípios recorreram ao trabalho de equipas técnicas para a execução do conjunto de critérios e passos metodológicos ${ }^{19}$ necessários ao

${ }^{19} \mathrm{Na}$ elaboração da Carta Educativa é necessário proceder à caracterização da totalidade da rede escolar municipal (estado de conservação, as condiç̃es e o numero de salas, índices de ocupação e taxas de cobertura); delimitação dos territórios educativos (área de influencia de cada estabelecimento de ensino, definida a partir dos fluxos escolares e fluxos laborais inter e intramunicipais); análise da hierarquização dos aglomerados populacionais, da rede viária existente e prevista; elaboração de estimativas relativas as necessidades de oferta educativa para os próximos anos letivos; etc. 
desenvolvimento do planeamento. As equipas técnicas que trabalharam na elaboração das Cartas Educativas são de natureza distinta: externas (universidades, empresas) e internas (técnicos municipais), encontrandose as primeiras em larga maioria.

Destaca-se a "visão" das equipas técnicas externas, sobre três aspetos: "participação"; "qualidade" e "condicionalismos" na elaboração das Cartas Educativas, bem como dos "tipos de planeamento".

\section{A - "Participação" das equipas técnicas}

A complexidade e especialização do trabalho inerente ao planeamento prospetivo da rede escolar, o reconhecido défice de recursos humanos capacitados para elaborarem a Carta Educativa e a necessidade de obter pareceres técnicos favoráveis pela Direção Regional de Educação do Centro (DREC) e pelo GEPE, encontram-se entre as principais razões apontadas pelas equipas técnicas para justificar a sua escolha pelos municípios.

0 balanço que as equipas técnicas fazem sobre a sua "participação" na elaboração das Cartas Educativas é bastante positivo. Em todos os casos, consideram muito relevante o contributo do seu trabalho, em virtude de ter permitido garantir cientificidade e tecnicidade exigidas para a construção da Carta Educativa, requisitos para os quais os municípios "não estavam preparados". Por outro lado, o trabalho de levantamento de campo desenvolvido por algumas das equipas (georreferenciação, registo fotográfico dos estabelecimentos, inquérito sobre as questões físicas dos edifícios, recotha de dados sobre as dinâmicas de procura e oferta escolares e a evolução demográfica e socioeconómica do município e reuniões com órgãos das escolas) foi essencial para permitir a concretização de um "diagnóstico dinâmico" e de soluções "mais credíveis". Condições que consideram ter sido essenciais para garantir a apreciação positiva por parte da DREC e do GEPE, como a própria homologação pelo governo.

\section{B - "Condicionalismos" na elaboração das Cartas Educativas}

Foi igualmente reconhecido que o trabalho técnico desenvolvido e respetivo resultado variaram consoante as características territoriais do município, os objetivos políticos e educativos do executivo municipal, as dinâmicas e resistências comunitárias existentes no momento e, o tempo e financiamento previsto para a sua realização. Estas condicionantes levaram a que o trabalho de planeamento viesse a ser induzido por fatores "extrínsecos". Simultaneamente, as condições "intrínsecas" das equipas técnicas (natureza, dimensão, formação, experiência na área e conhecimento do território) são fatores que, na opinião dos entrevistados, contribuem para explicar o maior ou menor rigor na recolha e tratamento dos dados, a diferença nos métodos utilizados para as projeções demográficas, e a exaustividade ou superficialidade na compreensão do território.

As equipas técnicas consideram que estes condicionalismos explicam, em larga medida, a existência de Cartas Educativas muito distintas em termos de "qualidade", "utilidade" e "prospetividade".

\section{C - "Tipos de planeamento"}

O desenvolvimento do trabalho pelas equipas técnicas foi distinto. Registam-se casos em que as equipas técnicas desenvolveram um trabalho de "encomenda"; ou seja, as decisões políticas já estavam tomadas e o planeamento foi desenvolvido tendo em conta as soluções previamente traçadas pelo executivo municipal. Essa "encomenda" é variável consoante o posicionamento e lógicas do município face às orientações emanadas pela tutela para a reorganização da rede escolar. Regista-se dois tipos de "encomenda" : (i) o planeamento deve ser compaginado com os objetivos determinados pelo Ministério da Educação; (ii) o planeamento deve "contornar" ou "desvalorizar" as orientações da tutela por forma a responder aos "compromissos políticos" previamente assumidos ao nível local, ou a posições ideológicas distintas sobre o que deve ser o planeamento da rede escolar municipal. Na opinião das equipas técnicas que desenvolveram o planeamento de "encomenda" tendo em conta os "compromissos" ou as posições ideológicas dos Executivos afirmam que o resultado final das Cartas Educativas tem a sua concretização mais dificultada e são aquelas que necessitam mais rapidamente de revisão.

Nos casos mais frequentes, o planeamento foi alvo de interferências ou mesmo de "pressões legítimas" face ao dinamismo político e comunitário do município. As equipas técnicas reconhecem que nos municípios onde isso aconteceu resultou num "planeamento de compromisso", ou seja, procura acomodar as orientações propostas pelo município sem comprometer, em demasia, o planeamento e os cenários propostos.

Em qualquer dos casos, as equipas reconhecem a importância da sustentação técnica como apoio à negociação, à decisão política e ao modo como a ação municipal é contextualizada e diversificada nos sistemas concretos da ação pública. 


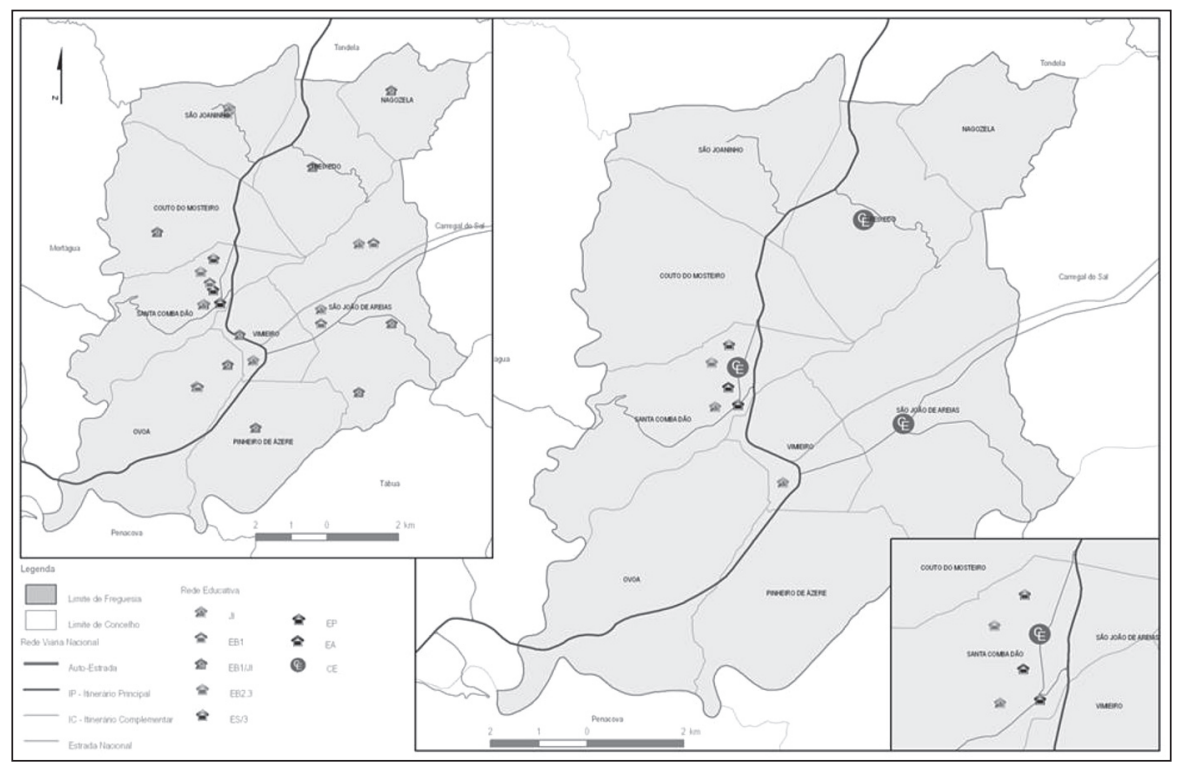

Figura 7

Análise comparativa entre o momento inicial e final da reorganização da rede educativa do município de Santa Comba Dão

\subsection{Tendências de reordenamento da rede escolar}

Da análise de conteúdo efetuada sobre as soluções de planeamento e reorganização da rede escolar $\left(1^{\circ} \mathrm{Ciclo}\right.$ e Educação de Pré-escolar) contidas nas Cartas Educativas (documento oficial) e tendo em conta as dimensões de análise - encerramento de escolas do $1^{\circ} \mathrm{Ciclo} \mathrm{e} \mathrm{jardins-de-infância;} \mathrm{concentração} \mathrm{da} \mathrm{rede;}$ distribuição espacial da rede escolar no território municipal; diversidade de tipologias e dimensão dos alunos em mobilidade - tornou-se possível identificar três tipos de soluções prevalentes de reordenamento: (1) do "tipo decretado"; (2) do "tipo conciliação"; (3) do "tipo comunitário".

\subsubsection{Reorganização do tipo "decretado"}

No primeiro caso, entende-se por "reorganização decretada" quando as soluções propostas de reorganização da rede escolar têm total correspondência com as defendidas pelo Estado central. Elas resultam de uma regulação local (município versus comunidade educativa) sem grandes tensões, cujo mosaico de interesses locais é compaginável, pelo menos na aparência, com os objetivos e estratégias das políticas educativas decretadas pelo Ministério da Educação neste domínio. Deste modo, as soluções do "tipo decretado" estão sustentadas em lógicas de predomínio técnico-administrativas e pressupõem uma imbricação político-normativa das soluções locais às políticas decididas pelo "centro".
Aqui, constata-se a existência de micro-regulação ${ }^{20}$ local "rendida" aos méritos de uma proposta tecnicamente competente, eficaz e eficiente.

Este tipo de reorganização conduz à passagem de uma distribuição da espacial da rede assente na lógica de proximidade, para uma lógica de eficiência/eficácia, onde se observa uma forte preocupação em criar igualdade de acesso ao ensino de qualidade a todos os alunos do município, sejam eles de sectores urbanos ou aos que apresentam maior ruralidade (Figura 7).

Entre os resultados mais visíveis do reordenamento do "tipo decretado "encontram-se o encerramento de um número expressivo de escolas, a opção por uma rede escolar fortemente concentrada, o aumento significativo do número de alunos em mobilidade e a posta no Centro Escolar como solução privilegiada de reordenamento - escala e qualidade.

Os dados revelam que nos municípios que optaram por soluções de reordenamento de tipo "decretado" a sua concretização têm uma elevada correspondência as propostas formuladas. A imbricação político-administrativa entre o município e o poder central, o cumprimento integral dos requisitos para o acesso ao financia-

${ }^{20}$ A micro-regulação local é aqui entendida como o "processo de coordenação da ação dos atores no terreno que resulta do confronto, interação, negociação ou compromisso de diferentes interesses, lógicas, racionalidades e estratégias em presença, quer numa perspetiva vertical entre "administradores" e "administrados", quer numa perspetiva horizontal, entre os diferentes ocupantes do mesmo espaço de interdependência (intra e inter organizacional)" (BARRoso, 2004: 17-18). 
mento do QREN, e a valorização do grau de eficiência e eficácia das soluções de reordenamento pela administração educativa, encontram-se entre as principais razões apontadas para explicar a consonância existente entre o plano de intenção e o plano da ação.

\subsubsection{Reorganização do "tipo conciliação}

Denominou-se por "reorganização de conciliação" quando as soluções encontradas tenderam a harmonizar as soluções emanadas pelo Estado com as defendidas pelo município. Aqui, as soluções de reorganização são "construídas" numa arena política de baixa intensidade ou mesmo mitigada, onde os municípios e o Estado procuraram, através de um processo compósito de "perdas e ganhos", chegar a soluções que satisfaçam tanto o "centro" como a "periferia". Dito de outro modo, as Cartas Educativas deste "tipo" resultaram de processos de confrontação, negociação e recomposição de objetivos e poderes caracterizados por ajustamentos e reajustamentos dos feixes de dispositivos reguladores que muitas vezes se anulam entre si, ou pelo menos, relativizam a relação causal entre princípios, objetivos, processos e resultados.

A reorganização de "conciliação" conduz assim a soluções de reorganização "mista" (Figura 8), ou seja, à coexistência de zonas do território com uma rede esco- lar bastante concentrada e outra mais dispersa (urbano vs rural); à compatibilização entre lógicas de proximidade com lógicas racionalizadoras; à existência de tipologias diversificadas, onde centros escolares coexistem com escolas "primárias" de baixa densidade ("entre o muito novo e o muito velho"); e o aumento de alunos em mobilidade é sentido apenas em algumas zonas do território municipal.

As características deste tipo de reorganização contribuem para que a sua concretização não corres pondam integralmente às propostas formuladas. A imposição do Ministério da Educação de encerramento de escolas não previstas na carta educativa e a dificuldade em obter financiamento para alguns dos projetos, sobretudo nas zonas do território onde a rede se mantém dispersa, são fatores apontados para que materialização das propostas seja mais fácil de atingir nas zonas urbanas e mais difícil nas zonas rurais. Necessidade de reformulação de algumas propostas, projetos e investimentos e atraso na execução são algumas das consequências visíveis.

\subsubsection{Reordenamento do "tipo comunitário".}

No último caso, a "reorganização comunitária" verifica-se quando prevalecem soluções que correspondem maioritariamente às reivindicações do mosaico de atores

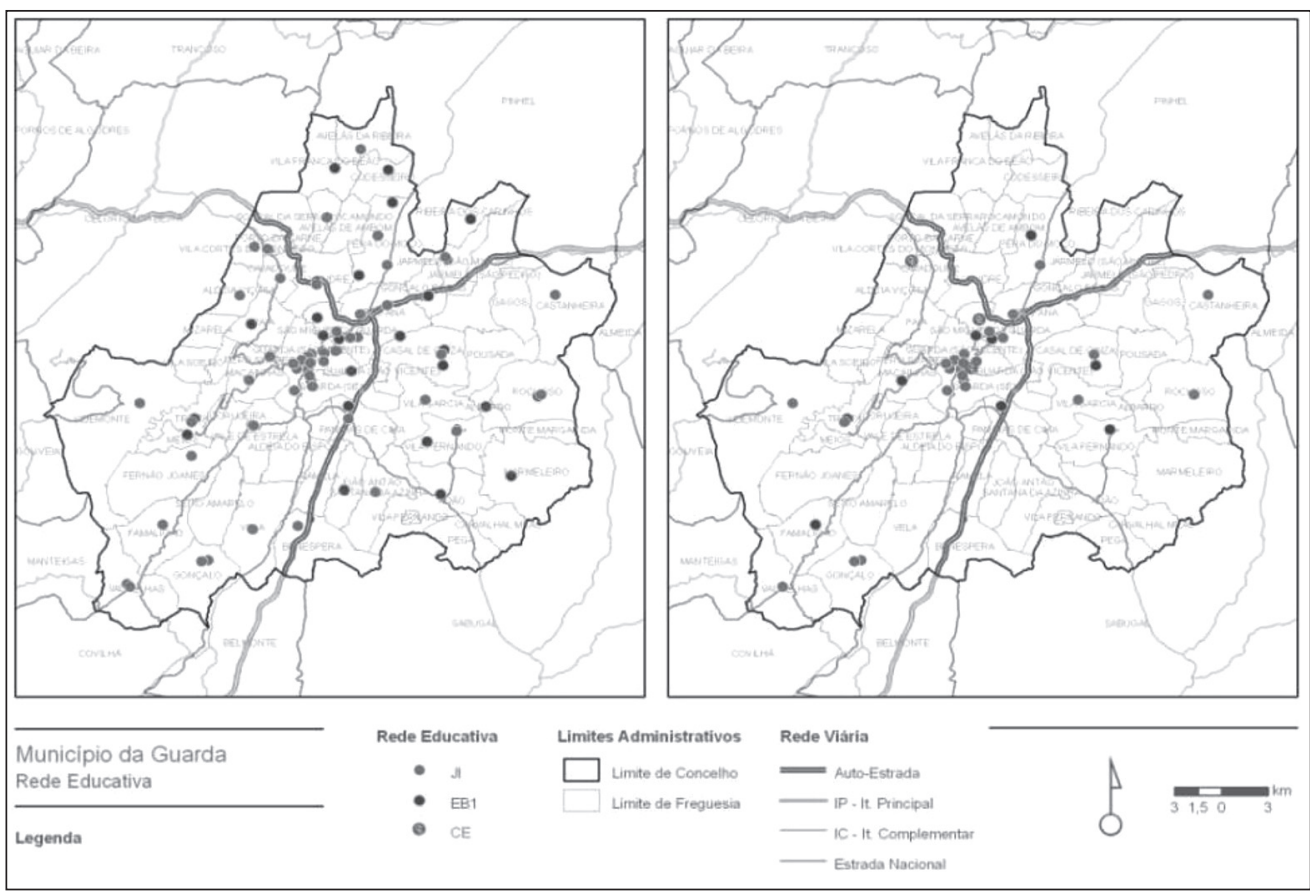

Figura 8

Análise comparativa entre o momento inicial e final da reorganização da rede educativa do município da Guarda. 
locais (Figura 9), sobrepondo-se ou ignorando, em larga medida, os critérios e objetivos definidos centralmente.

Neste tipo de reorganização, ao contrário do que se verifica na reorganização decretada, são os interesses políticos e sociais locais que se sobrepõem, num complexo jogo de estratégias, negociações e ações protagonizadas pelos vários atores locais. As soluções de reorganização da rede escolar, neste caso, resultam de tensões políticas vincadas entre o município e o Estado, onde a força e influência política local procuram secundarizar ou mesmo contrariar a força político-normativa do poder central. Aqui imperam as lógicas comunitárias dos "administrados" face às lógicas institucionais dos "administradores".

Como resultado, as soluções de reorganização são de "baixa intensidade", ou seja, a distribuição geográfica da rede escolar sofre poucas alterações (exemplo, uma escola por freguesia); os parâmetros de escala e de requalificação são menos expressivos; há a manutenção de escolas com poucos alunos; a aposta é a manutenção de uma rede de proximidade; um reduzido aumento de alunos em mobilidade; e a opção pelo centro escolar é exceção.
Ao nível da concretização a reorganização "comunitária" é aquela que apresenta maior discrepância entre as propostas e o que é efetivamente realizado. 0 encerramento de um número de um número significativo de escolas pela tutela e o não financiamento para requalificação de escolas e para a construção de centros escolares de diminuta dimensão têm obrigado os municípios que optaram por este tipo de reorganização a assinaláveis mudanças no plano da execução: localização, dimensão dos estabelecimentos de ensino; reformulação de projetos e alteração dos planos de execução e financiamento.

Após as apreciações elaboradas sobre as soluções de reorganização da rede educativa, importa sublinhar que as tendências não se esgotam nos três "tipos" identificados. A investigação permitiu confirmar a existência de cartas educativas que espelham soluções intermédias ou, ainda, casos há em que situam muito próximas de uma das reorganizações identificadas. Por outro lado, a mudança da cor política do município, as dificuldades financeiras, a pouca capacidade de diálogo e de influência junto da administração educativa e o contexto mais geral de crise económica e financeira com

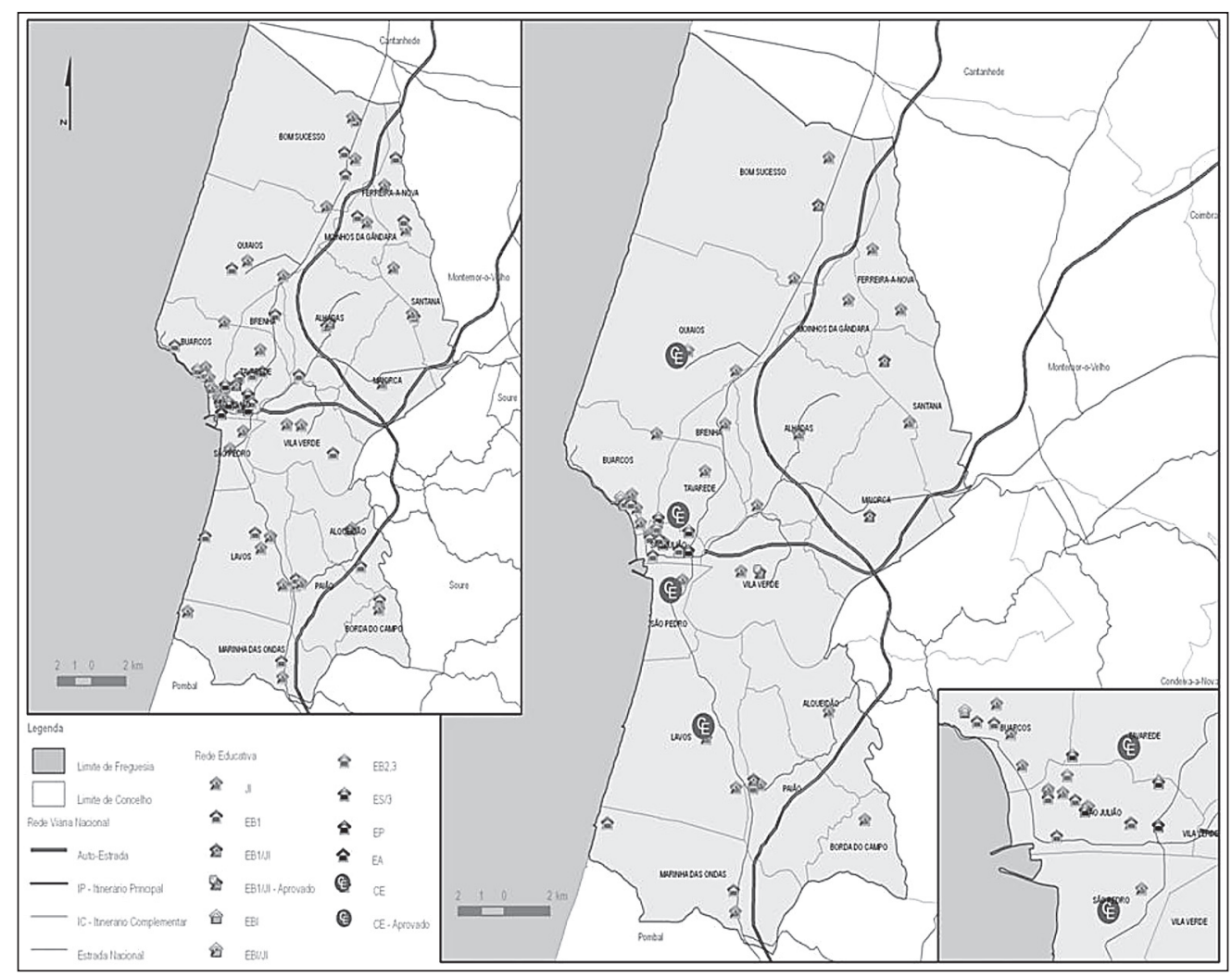

Figura 9

Analise comparativa entre a fase inicial e final da reorganização da rede educativa do município da Figueira da Foz. 
que o país está confrontado, são fatores que também contribuem para influenciar o grau de correspondência entre as propostas de reorganização e a execução das Cartas Educativas.

Em qualquer um destes tipos de soluções existe um problema comum, à grande maioria dos municípios: a falta de um trabalho de diagnóstico profundo, que deveria ter antecedido a elaboração das propostas de reorganização da rede educativa. Esta etapa deveria ter contemplado a análise da população escolar e dos fluxos associados a cada estabelecimento de ensino, incluindo, caso existisse, a observação da área de influência definida, e a realização das projeções demográficas, quer da população residente, mas, acima de tudo, da população escolar prevista para os próximos anos letivos nos diferentes níveis de ensino. Sem o cumprimento desta fase dificilmente qualquer proposta de reorganização da rede educativa apresentada será bem conseguida e obedecerá aos princípios do verdadeiro planeamento estratégico.

\subsection{A "visão" dos autarcas}

A visão dos autarcas sobre a Carta Educativa e o processo que a envolve é globalmente positiva, embora o "entusiasmo" ou a "energia" das críticas varie em função da dimensão do município, do grau dos problemas que são necessários resolver, do nível de apoio político com que conta internamente, da posição ideológica, ou mesmo da capacidade de influência que detém, quer ao nível local quer junto do poder central e da administração educativa.

O balanço da nossa investigação sobre a "visão" dos autarcas relativa ao processo das cartas educativas sinaliza constrangimentos e vantagens que importam assinalar: (i) os constrangimentos remetem para a elaboração e execução da Carta Educativa ser fortemente condicionada pelo Estado Central; a fraca flexibilidade da administração educativa em face das especificidades e vontades locais; a comparticipação financeira pouco flexível e condicionadora das soluções de reordenamento; a administração educativa desconcentrada muito pouco presente no terreno; a passagem dos municípios a um papel de "meros executores"; e, por último, e apesar da transferência de competências do Estado, a manutenção do seu poder quase intacto; (ii) as vantagens estão associadas à possibilidade, ainda que mitigada, do município adaptar a "sua" rede escolar às características territoriais, populacionais e educativas; ao envolvimento dos principais atores locais na discussão da rede educativa; à contribuição que presta ao município no aprofundamento do seu conhecimen- to sobre o território educativo e na maior capacitação para tomar decisões e para negociar com o poder central; à requalificação da rede através da construção de Centros Escolares, resposta de qualidade à mudança de paradigma da escola do $1^{\circ} \mathrm{CEB}$; e, por último, ao planeamento prospetivo que "obrigou" os municípios a ter uma visão de futuro.

\section{Conclusão}

Em síntese, é possível afirmar que a configuração do planeamento e das soluções de reorganização da rede educativa municipal é um processo compósito e multi-regulado, capitaneado por lógicas diferenciadas, consoante o contexto geográfico, político e a "força" e dinamismo que se estabelecem no contexto inframunicipal e entre cada município e o Estado central.

O trabalho de planeamento desenvolvido pelas equipas técnicas "externas" revelou-se importante para suprir a falta de capacidade e preparação dos municípios para desenvolverem esse trabalho. O resultado desse trabalho funcionou como elemento "facilitador" para a obtenção da aprovação da Carta Educativa pela tutela. Não obstante, é reconhecido que a "qualidade" técnica das Cartas Educativas é condicionada pelo "tipo de planeamento" - encomenda e compromisso - que é solicitado pelos municípios, por fatores inerentes à natureza e composição das próprias equipas e, pela interferência de lógicas políticas e comunitárias no planeamento da rede escolar. As "boas" soluções técnicas nem sempre correspondem às soluções aprovadas no plano político, não obstante o papel que thes é atribuído por municípios na legitimação e promoção das "reformas" da rede escolar municipal.

As diferentes tendências de reorganização identificadas - decretado, conciliação e comunitário - sublinham, não só a existência de diferentes práticas e posicionamentos dos municípios face à reorganização da rede, como contribuem para a desocultação e compreensão da multiplicidade de processos regulatórios entre o "centro" e as suas "periferias".

Simultaneamente, a "visão" dos autarcas sobre o processo das Cartas Educativas permite constatar que o processo de planeamento e reorganização da rede, no contexto de aprofundamento da territorialização das políticas de educação, apesar dos constrangimentos detetados, contribuiu para o aprofundamento da participação do município neste domínio. Em face desta constatação, é possível concluir que, hoje, os municípios estão melhor capacitados para fazer face aos 
desafios presentes e futuros, nomeadamente no que respeita à construção de um projeto educativo de base municipal.

\section{Referências bibliográficas}

Afonso, Natércio (2005) - Investigação Naturalista em Educação - um guia prático e crítico. Coleção em foco. Porto: Edições ASA.

Amiguinho, Abílio; Afonso, Carlos; Brandão, Carlos (1998) Dinâmicas de integração, organização e funcionamento numa Escola Básica Integrada. Estudo de caso. Lisboa, Ministério da Educação.

Barreto, António (org.) (1996) - A situação Social em Portugal, 1960-1995, Lisboa, ICS.

BARRoso, João (1992) - "Factores pedagógicos e educativos da Carta Escolar". In: Carta Escolar da Região Centro (Seminário de Coimbra - Outubro de 1990). Lisboa, Gabinete de Estatística e Planeamento da Educação/ Ministério da Educação, pp. 79-92.

BARRoso, João (2003) - "A "escolha da escola" como processo de regulação: integração ou selecção social”. In: BARRoso, João (Org. ) - A escola pública: regulação, desregulação, privatização. Porto, ASA, pp. 79-109.

BARRoso, João e VISEU, Sofia (2003) - "A emergência de um mercado educativo no planeamento da rede escolar: de uma regulação pela oferta a uma regulação da pela procura". Educação \& Sociedade, vol. 24, n. ${ }^{\circ} 84$, pp. 897-921.

CAndeIAS, António, (org.) (2004) - Alfabetização e Escola em Portugal nos Séculos XIX e XX. Lisboa, Fundação Calouste Gulbenkian.

CARDoso, Clementina (2003) - "Do público ao privado: gestão racional e critérios de mercado, em Portugal e Inglaterra". In: BARRoso, João (org.) - A escola pública: regulação, desregulação privatização. pp. 149-191.

Carvalho, Rómulo (1994) - História do Ensino em Portugal. Lisboa, Fundação Calouste Gulbenkian.

Comissão de Reforma do Sistema Educativo (1988) - Proposta Global de Reforma. Lisboa, GEP-ME.

CoRdeIRo, A. M. Rochette (2011) - "Reorganização da rede escolar". O boletim dos professores, 20. Lisboa, Ministério da Educação, pp. 2-3.

Costa, Jorge A.; Neto-Mendes, António e Sousa, Liliana (2001) Gestão Pedagógica e Lideranças Intermédias na Escola: estudo de caso no TEIP do Esteiro. Aveiro: Universidade de Aveiro.

Fernandes, António (2004) - "Município, cidade e territorialização educativa". In: COSTA, JoRGE et al. Políticas e gestão local da educação. Aveiro, Universidade de Aveiro, pp. 35-43.
FonsECA, J. (1981) - "Gestão do sistema de ensino". In SILVA, Manuela e TAmen, Isabel (coord.) Sistema de Ensino em Portugal. Lisboa, Gulbenkian, pp. 117-142.

FormosinHo, João (1988) - "Princípios para a organização da escola portuguesa". In: CRSE $A$ gestão do sistema escolar. Lisboa, Ministério Da Educação/Comissão da Reforma do Sistema de Ensino, pp. 53-102.

Formosinho, João (1998) - O Ensino Primário: de ciclo único do ensino básico a ciclo intermédio da educação básica, Cadernos PEPT, 21. Lisboa, Ministério da Educação.

FormosinHo, João (2005) - "Centralização e descentralização na administração da escola de interesse público". In: Formosinho, J.; Fernandes, António; Machado, Joaquim e FerReira, Fernando - Administração da Educação: Lógicas Burocráticas e Lógicas de Mediação. Porto, Asa, pp. 1352.

FormosinHo, João e MACHADO, Joaquim (2008) - "Currículo e organização: as equipas educativas como modelo de organização pedagógica". Currículo sem Fronteiras, vol. $8, \mathrm{n}^{\circ} 1$, pp. 5-16.

FormosinHo, João et al. (2005) - Administração da Educação: Lógicas Burocráticas e Lógicas de Mediação. Porto, Asa

Gabinete de estatística e pLaneamento da educação/Instituto nacional de estatística (2009a) 50 anos de estatística de educação Volume I. Lisboa, Ministério da Educação.

Gabinete de estatística e planeamento da educação/Instituto nacional dE ESTATÍSTICA (2009b) - 50 anos de estatística de educação Volume III. Lisboa, Ministério da Educação.

Gomes, Joaquim Ferreira, Fernandes, Rogério e Grácio, Rui (1988) - História da Educação em Portugal. Lisboa, Livros Horizonte.

GrácIo, Rui (1981) - Educação e Processo Democrático em Portugal. Lisboa, Livros Horizonte, pp. 12-44.

GrácIo, Rui (1986) - "Educação, Dez anos Depois". Revista Crítica de Ciências Sociais, n 18/19/20, pp. 153-182.

LIMA, Jorge Ávila (2007) - "Redes na educação: questões políticas e conceptuais". Revista Portuguesa de Educação, 20 (2), pp. 151-181.

LimA, Licínio (2004) - "O agrupamento de escolas como novo escalão da administração desconcentrada". Revista Portuguesa de Educação, 17 (2), pp.7-47.

LimA, Licínio et al. (2006) - "Administração da Educação e autonomia das escolas". In Conselho Nacional de Educação. A Educação em Portugal (1986-2006): alguns contributos de investigação. Sociedade Portuguesa de Ciências da Educação.

LımA, Licínio (2011) - Administração Escolar: Estudos. Porto, Porto Editora.

MACEDo, Berta e Afonso, Natércio (2002) - "Desenvolvimento dos modos de regulação". In BARRoso, João et al. - Análise da evolução dos modos de regulação institucional do 
sistema educativo em Portugal. Lisboa, Universidade de Lisboa (FPCE), pp.73-87.

MarTins, Carlos Alves (1968) - "Alguns aspectos do ensino em Portugal”. Análise Social, 6 (20-21), pp. 57-80.

MarTins, Carlos Alves et al (1964) - Projecto Regional do Mediterrâneo: evolução da estrutura escolar portuguesa (Metrópole). Previsão para 1975. Lisboa, Instituto Superior de Ciências Económicas e Financeiras.

MARTINS, Helena; CoRdeIRo, A. M. Rochette (2011) - "Carta Educativa. Instrumento estratégico de reorganização da rede educativa: tendências e "olhares" dos municípios". In: Cordeiro, António; Alcoforado, Luís e Ferreira, António Gomes (coord.) - Das Cartas Educativas ao Projecto Educativo Local. Novas perspectivas sobre a Municipalização da Educação. Coimbra, Universidade de Coimbra/ Câmara Municipal da Figueira da Foz., pp. 3-13.

Martins, Helena; Neto-Mendes, António; Cordeiro, A. M. Rochette (2011) - "Cartas Educativas: um olhar sobre soluções de reordenamento da rede escolar e mudanças no(s) território(s)". In Actas do II Encontro de Sociologia da Educação: Educação, Territórios e [Des]lgualdades. Porto, Faculdade de Letras da Universidade do Porto, pp. 336-367.

Matthews, Peter, et al. (2009) - Política Educativa para o $1^{\circ} \mathrm{Ciclo}$ do Ensino Básico (2005-2008) - Avaliação Internacional. Lisboa, GEPE-ME.

MINISTÉRIO dA Educação (1990) - Critérios de Planeamento da Rede Escolar. Lisboa, Ministério da Educação/Gabinete de Estudos e Planeamento.

MInISTÉRIO dA EducaÇão (1992) - Carta Escolar da Região Centro (Seminário de Coimbra - Outubro de 1990). Lisboa, Gabinete de Estatística e Planeamento da Educação/ Ministério da Educação.

MinistérIo da Educação (2005) - O boletim dos Professores, 1. Lisboa, Ministério da Educação.

MINISTÉRIO DA EduCAÇÃo (2011a) - Edifícios para o Ensino Infantil e Primário. Da escola piloto à área aberta. Lisboa, Ministério da Educação, Col. Muitos Anos de Escolas, vol. III.

MINISTÉRIO dA EducAÇÃo (2011b) - Educação em números - Portugal 2011. Lisboa, Ministério da Educação/Gabinete de Educação de Estatística e Planeamento da Educação.

MinistérIO dA EducaÇão (2011c) - O boletim dos professores, 20. Lisboa: Ministério da Educação.

Neto-Mendes, António (1995) - Escola Básica Integrada: a "nova" escola e os "velhos" professores. Estudo de caso. Braga, Instituto de Educação e Psicologia da Universidade do Minho (tese de mestrado não publicada).

NóvoA, António (1988) - "A história do ensino primário em Portugal". In Fernandes, R. (Org.) - I Encontro de História da Educação em Portugal. Lisboa, Fundação Calouste Gulbenkian, pp. 23-29.

NóvoA, António e d’ó, Jorge Ramos (2007) - "Educação". In: Fundação Gulbenkian - 50 anos de História. Lisboa, Fundação Calouste Gulbenkian.

Pimenta, Paulo (2006) - A escola portuguesa. Do "Plano dos Centenários" à construção da rede escolar do distrito de Vila Real. Braga, Universidade do Minho (dissertação de mestrado; policopiada).

PInto, Maria Mota (1992) - "Condições de oferta na Região centro". In: Carta Escolar da Região Centro (Seminário de Coimbra - Outubro de 1990). Lisboa, Gabinete de Estatística e Planeamento da Educação/ Ministério da Educação, pp. 47-52.

PIRES, Eurico Lemos (2000) - Nos meandros do labirinto escolar. Oeiras, Celta.

PIRES, Eurico Lemos (1993) - Escolas Básicas Integradas como Centros Locais de Educação Básica. Porto, Sociedade Portuguesa de Ciências da Educação.

PIREs, Eurico Lemos (1988) - "A massificação escolar". Revista Portuguesa de Educação, vol. 1, n 1, pp. 27-43.

PIRES, Eurico Lemos (1987) - Lei de Bases do sistema Educativo. Apresentação e comentários. Porto, ASA.

Quivy, R. e CAMPENHoudt, L. (1992) - Manual de Investigação em Ciências Sociais. Lisboa. Gradiva.

ReIS, Jaime (1993) - "O analfabetismo em Portugal: uma interpretação". In: Colóquio Educação e Sociedade, 2 , pp 13-40.

Rodrigues, Maria de Lurdes (2010) - A Escola Pública Pode Fazer a Diferença. Coimbra, Almedina.

SANTOS, Boaventura de Sousa (1990) - O estado e a sociedade em Portugal (1974-1988). Porto, Afrontamento.

Stake, R. (1998) - "Case studies". In: Denzin, N. e Lincoln, Y. (eds.) - Handbook of qualitative research. Thousands Oaks, Sage.

Stoer, Stephen (1986) - Educação e mudança social, 1970-80: uma década de transição. Porto, Edições Afrontamento.

Stoer, Stephen; Stoleroff, Alan; Correia, José Alberto (1990) - "O novo vocacionalismo na política educativa em Portugal e a reconstrução da lógica da acumulação". Revista Crítica de Ciências Sociais, 29, 11-53.

TEOdoRo, António (1995) - "Reforma Educativa ou a Legitimação do Discurso sobre a Prioridade Educativa". Educação, Sociedade e Culturas, ${ }^{\circ} 4$, 1995, pp. 49-70

TEOdoro, António (2001) - A construção política da educação. Estado, mudança social e políticas educativas no Portugal contemporâneo. Porto, Edições Afrontamento.

YIN, Robert (1984) - Case study research: Design and methods. Newbury Park, CA, Sage. 